\title{
PATHOGENESIS OF EARLY EMBRYONIC MORTALITY CAUSED BY FASTING PREGNANT RATS AND MICE FOR SHORT PERIODS
}

\author{
T. J. McCLURE* \\ Ruakura Animal Research Station, Hamilton, N.Z.
}

(Received 7th March 1961)

\begin{abstract}
Summary. Daily treatment with progesterone and chorionic gonadotrophin was found to protect pregnancy in fasted mice so that it lasted at least 6 days longer than in control mice fasted from the end of the 3 rd to 5th days after mating. Pregnancy could not, however, be maintained beyond the 14th or 15th day by these means. The pathogenesis of the embryonic mortality caused by fasting, therefore, appears to involve a failure of hypophyseal gonadotrophic function. Adrenalectomy and implantation with desoxycorticosterone acetate did not protect pregnancy in fasted rats, suggesting that the mortality was not caused by hypersecretion of corticosterone.
\end{abstract}

\section{INTRODUCTION}

Embryonic mortality in mice may be brought about by fasting pregnant females for $48 \mathrm{hr}$ from the end of the 3rd day after mating (McClure, 1959, 1961). It is possible that the stress of fasting stimulates hypersecretion of corticosterone in lethal amounts for Robson \& Sharaf (1952) and Macfarlane, Pennycuick \& Thrift (1957) have shown that the injection of corticosterone and adrenocorticotrophic hormone can cause embryonic mortality in rats. Alternately, fasting may cause a failure of gonadotrophic function of the hypophysis thus terminating pregnancy, for Werner (1939), Pomerantz \& Mullinos (1939) and Rinaldini (1949) showed that chronic inanition in the rat resulted in anoestrum because of such a failure.

These two theories were examined experimentally. Unfortunately the strain of mice used in these experiments appeared to contain accessory adrenal cortical tissue rendering total adrenalectomy impossible for bilateral adrenalectomy did not result in progressive loss of body weight. Investigation of the part played by the adrenal cortex in the pathogenesis was therefore carried out on rats.

\section{MATERIALS, METHODS AND RESULTS}

TESTING OF THE CORTICOSTERONE THEORY

Virgin female albino rats about 3 months of age were pair mated with males of the same strain. Vaginal smears were made daily and examined for the presence

* Present address: Department of Veterinary Medicine, University of Sydney, Australia. 
of spermatozoa, the occurrence of which was taken as evidence of mating. After mating, the rats were divided into four groups: (a) fasted, (b) fasted, adrenalectomized, (c) control and (d) adrenalectomized control, containing forty, thirty-two, twenty and thirteen rats, respectively.

The rats in the adrenalectomized group were adrenalectomized on the day spermatozoa were found in the vagina and each was implanted with a 10-mg desoxycorticosterone acetate B.P. pellet. The rats in the fasted groups were fasted for two or three 48-hr periods, one, two, or three 72-hr periods, or one or three 96-hr periods, separated by 48-hr periods of feeding ad libitum. The first or only period of starvation started on the day spermatozoa were found. At all times other than during fasting, food pellets were available ad libitum. The pellets formed a complete diet and had proved adequate for normal growth and reproduction. Water was freely available at all times. The rats were allowed sufficient time to complete their gestation, and the success or otherwise of the

TABLE 1

EFFECT OF TEMPORARY FASTS AND ADRENALECTOMY ON THE FERTILITY OF RATS

\begin{tabular}{|c|c|c|c|c|c|c|}
\hline \multirow{3}{*}{ Group } & \multicolumn{6}{|c|}{ Periods of fasting starting from the day of finding spermato zoa in the vagina } \\
\hline & \multicolumn{2}{|c|}{$\begin{array}{c}1 \times 72 h r, 2 \times 48 h r \\
3 \times 48 h r\end{array}$} & \multicolumn{2}{|c|}{$1 \times 96 h r$} & \multicolumn{2}{|c|}{$\begin{array}{c}2 \times 72 \mathrm{hr}, 3 \times 72 \mathrm{hr}, \\
3 \times 96 \mathrm{hr}\end{array}$} \\
\hline & $\begin{array}{l}6 / 13 \\
5 / 10\end{array}$ & $\begin{array}{l}(46 \%) \\
(50 \%)\end{array}$ & $\begin{array}{l}5 / 15 \\
5 / 14\end{array}$ & $\begin{array}{l}(33 \%) \\
(36 \%)\end{array}$ & $\begin{array}{l}1 / 12 \\
0 / 8\end{array}$ & $\begin{array}{l}(8 \%) \\
(0 \%)\end{array}$ \\
\hline & \multicolumn{6}{|c|}{ Not fasted } \\
\hline $\begin{array}{l}\text { Control } \\
\text { Control, adrenalectomized }\end{array}$ & \multicolumn{3}{|c|}{$\begin{array}{r}14 / 20 \\
9 / 13\end{array}$} & \multicolumn{3}{|c|}{$\begin{array}{l}(70 \%) \\
(69 \%)\end{array}$} \\
\hline
\end{tabular}

Results given are of the number and proportion of rats that were pregnant.

treatments was judged by the number of rats which littered. The range of fasting was designed to find the minimal fast required to cause infertility in rats. The number of rats littering in each group is shown in Table 1.

TESTING OF THE GONADOTROPHIC FUNGTION THEORY

Ten-week-old virgin white mice of the Ruakura strain were pair mated and fed ad libitum on the standard pelleted food. The mice were examined daily for copulation plugs, the presence of which was taken as evidence of mating. Excepting the control group, the mice were fasted for a 48-hr period from the end of the 3rd day after finding the plugs. Water was always freely available. Three hundred and ten female mice, including 109 control mice were used in the experiment, which was conducted in sections over a period of 1 year. Nine groups of mice were given the following treatments:

(a) Control (forty-two mice). These were neither fasted nor treated and were killed on the 4th to 11 th days after mating or else allowed to litter.

(b) Control fasted (sixty-seven mice). These were fasted but not treated and were killed on the 4th to 11 th days after mating or else allowed to litter. 


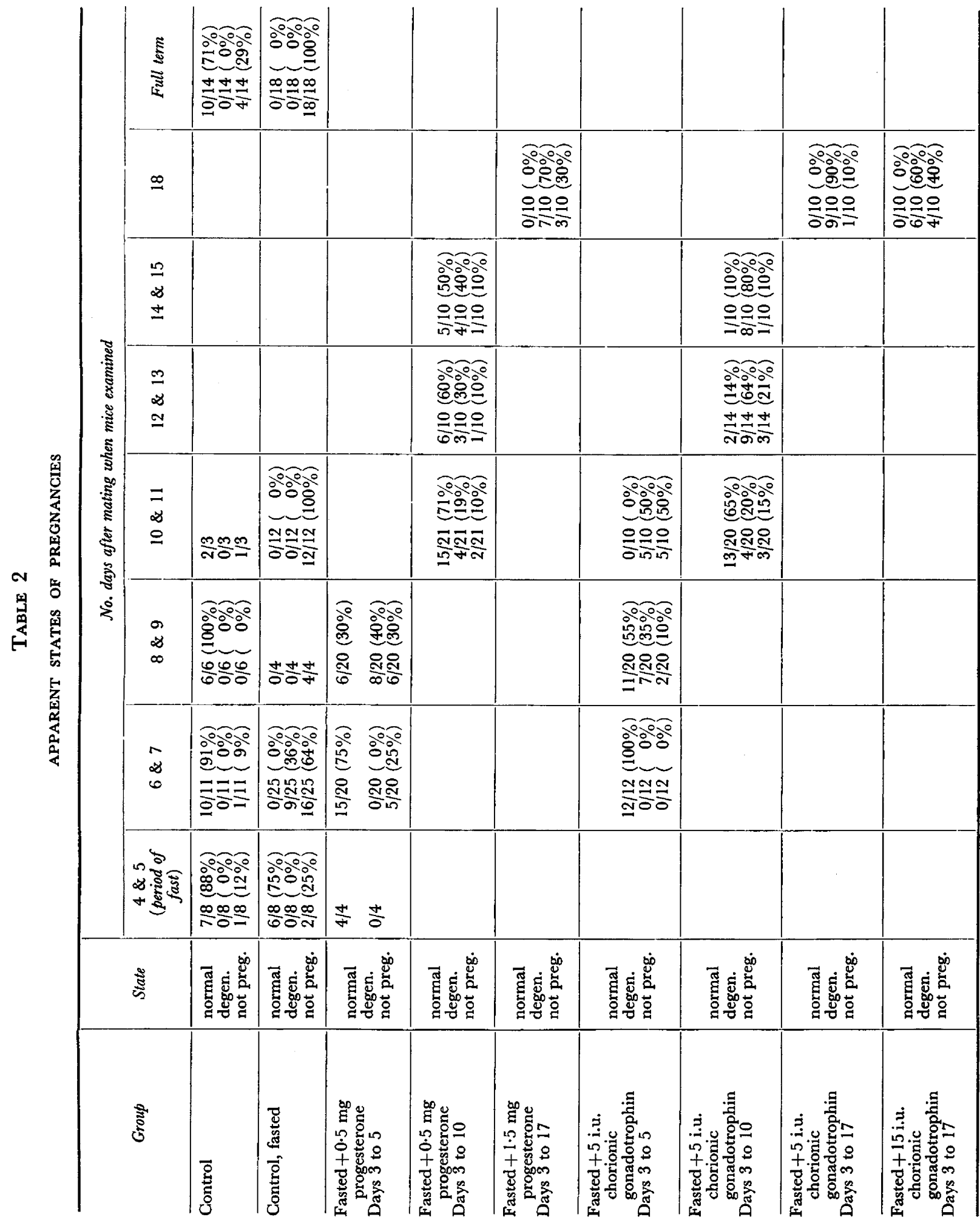


(c) Three groups of mice which were fasted and given progesterone subcutaneously:

(i) Forty-four mice, $0.5 \mathrm{mg}$ daily at the end of the 3rd, 4th and 5 th days after mating and were killed on the 4th to 9 th days.

(ii) Forty-one mice, $0.5 \mathrm{mg}$ daily from the end of the 3rd to 10th days after mating and were killed on the 10th to 15 th days.

(iii) Ten mice, $1.5 \mathrm{mg}$ daily from the end of the $3 \mathrm{rd}$ to 17 th days and were killed on the 18th day.

(d) Four groups of mice which were fasted and given chorionic gonadotrophin subcutaneously:

(i) Forty-two mice, 5 i.u. daily at the end of the $3 \mathrm{rd}, 4$ th and 5 th days after mating and were killed on the 6 th to 11 th days.

(ii) Forty-four mice, 5 i.u. daily from the end of the 3rd to 10 th days after mating and were killed on the 10 th to 15 th days.

(iii) Ten mice, 5 i.u. daily from the end of the 3 rd to 17 th days and were killed on the 18th day.

(iv) Ten mice, 15 i.u. daily from the end of the 3 rd to 17 th days and were killed on the 18 th day.

The uteri of the killed mice were examined and the state of the pregnancies assessed by macroscopic examination of the uteri and their contents and, where doubtful, confirmed microscopically. The numbers of mice (a) normally pregnant, (b) with degenerating deciduomata and embryos and (c) not pregnant and with no evidence of having been pregnant are shown in Table 2.

\section{DISCUSSION}

Whereas in the mice two 48-hr periods of fasting, starting from oestrus and separated by a period of $48 \mathrm{hr}$ of feeding ad libitum caused zero fertility (McClure 1959), at least two periods of $72 \mathrm{hr}$ were necessary to produce comparable results in rats in the present experiment. Fewer periods, or shorter periods of fasting did, however, appear to reduce the number of rats littering. The critical stage of gestation, if any, was not determined for the rats as it was for the mice. Adrenalectomy did not appear to have any effect on the result, suggesting that the adrenal cortex is not involved to any great extent in the pathogenesis of the infertility. This is interesting, considering the observations made by FernandezCano (1958, a,b), showing that adrenalectomy alleviated the infertility effect of high environmental temperature and hypoxia, and Macfarlane's observation (personal communication) that high temperatures depressed the rats' appetites as well as causing embryonic mortality (Macfarlane et al., 1957). While it is unwise to argue from the rat to the mouse, it would seem unlikely that the adrenal cortex is involved to any great extent in the pathogenesis of the infertility in the latter species.

In the gonadotrophic function experiment, the mice in the control group were of normal fertility and none examined from the 4 th to 11 th days contained embryos or deciduomata which were obviously degenerating.

The mice in the control, fasted group conformed to the pattern shown earlier 
(McClure, 1961) of the pregnancy terminating during the $48 \mathrm{hr}$ after the end of the 48-hr period of fasting. None of the sixteen mice examined on the 8th to 1 I th days after mating, or the eighteen mice allowed to complete the gestation period, was pregnant. Progesterone in daily doses of $0.5 \mathrm{mg}$. over the period of fasting appeared to protect most of the embryos for 2 days after those of the control fasted mice showed signs of dying and resorption. Progesterone in daily doses of $0.5 \mathrm{mg}$ from the 3rd to 10th day after mating protected most of the embryos until at least the 11 th and in some cases the 15th day. Some embryos, however, were dying during this period. When progesterone was given in 1.5 $\mathrm{mg}$. daily doses from the $3 \mathrm{rd}$ to 17 th days after mating, none of the mice was normally pregnant when examined on the 18th day and all the embryos in $7 / 10$ of the mice were degenerating.

Chorionic gonadotrophin in daily doses of 5 i.u. given over the period of fasting protected all the pregnancies until the 7 th day. When examined between the 8th and 11 th days, many of the pregnancies were terminating. The protection thus afforded was for 2 to 4 days. In mice given chorionic gonadotrophin in similar daily doses from the 3rd to 10th days after mating, the pregnancies were normal in 13/20 on the 10th and 11 th day, but most were degenerating on the 12th and 13th days. The protection afforded was comparable with that of progesterone. None of the ten mice given chorionic gonadotrophin in doses of 5 i.u. daily from the 3 rd to the 17 th was normally pregnant and all the embryos and deciduomata of nine of the ten were degenerating when the mice were examined on the 18th day. The larger quantity of chorionic gonadotrophin, 15 i.u., produced similar results.

Thus, both progesterone and chorionic gonadotrophin in doses of $0.5 \mathrm{mg}$ and 5 i.u., respectively, given during the period of fasting appeared to delay the onset of embryonic death by about 2 days. When given from the 3rd to 10 th day after mating, the life of most of the embryos was prolonged until or just after the end of the course of treatment. The dose of progesterone used was less than that generally considered necessary for the maintenance of pregnancy. Robson (1938) estimated that in the pregnant mouse the concentration of progesterone was similar to that produced by the daily administration of 1.5 $\mathrm{mg}$ of the hormone. When progesterone was given daily in doses of $1.5 \mathrm{mg}$ from the 3rd to 17th day of pregnancy, none of the embryos of ten mice was normal on the 18th day. A similar result was produced by 15 i.u. chorionic gonadotrophic hormone. Both progesterone and chorionic gonadotrophin had a marked effect in counteracting the effect of fasting, thereby supporting the hypothesis that the embryonic mortality is caused by depression of hypophyseal function. However, in the doses and methods used they were not able to maintain normal pregnancy to term indicating that the normal placenta-ovary relationship was not established to enable pregnancy to continue through the second half of pregnancy.

\section{ACKNOWLEDGMENT}

'Acknowledgment is made to Mrs S. E. Fry for technical assistance. 


\section{REFERENCES}

Fernandez-Cano, L. (1958a) Effect of increase or decrease of body temperature and hypoxia on pregnancy in the rat. Fertil. $\mathscr{E}^{2}$ Steril. 8, 455.

Fernandez-Cano, L. (1958b) Effect of changes in body temperature and hypoxia on pregnancy in adrenalectomised rats. Fertil. $\mathcal{E}$ Steril. $\mathbf{8}, 460$.

MaClure, T. J. (1959) Temporary nutritional stress and infertility in female mice. $\mathcal{F}$. Phsyiol. 147, 221.

McGlure, T. J. (1961) Uterine pathology of temporarily-fasted pregnant mice. F. comp. Path. 71, 16.

Magfarlane, W. V., Pennycuick, P. R. \& Thrift, E. (1957) Resorption and loss of foetuses in rats living at $35^{\circ}$ C. F. Physiol. 135, 451 .

Pomerantz, L. \& Mullinos, M. G. (1939) Pseudo-hypophysectomy produced by inanition. Amer. $\mathcal{J}$. Physiol. 126, 601.

Rinaldint, L. M. (1949) Effect of chronic inanition on the gonadotropic contents of the pituitary gland. 7. Endocrin. 6, 54.

Rosson, J. M. (1938) Mechanism of oestrus inhibition in the mouse during pregnancy. Quart. F. exp. Biol. 28, 195.

Robson, J. M. \& Sharaf, A. A. (1952) Effect of adrenocorticotrophic hormone (ACTH) and cortisone on pregnancy. 7. Physiol. 116, 236.

WERner, S. C. (1939) Failure of gonadotropic function of the rat hypophysis during chronic inanition. Proc. Soc. exp. Biol., N.Y. 41, 101. 